\title{
New polyhydroxylated steroids from the marine pulmonate Trimusculus peruvianus
}

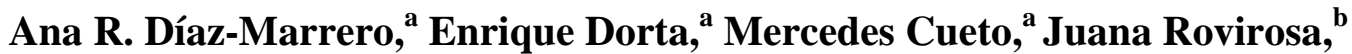 \\ Aurelio San-Martín, ${ }^{b}$ Alberto Loyola, ${ }^{c}$ and José Darias ${ }^{\mathrm{a} *}$ \\ ${ }^{a}$ Instituto de Productos Naturales y Agrobiología del CSIC, Avda. Astrofísico F. Sánchez 3, Apdo \\ 195, 38206 La Laguna, Tenerife, Spain, ${ }^{b}$ Departamento de Química, Facultad de Ciencias, \\ Universidad de Chile, Santiago de Chile, Chile and ${ }^{c}$ Departamento de Química, Facultad de \\ Ciencias, Universidad de Antofagasta, Antofagasta, Chile \\ E-mail: jdarias@ipna.csic.es
}

\section{Dedicated to Professor Edmundo A. Rúveda on his $70^{\text {th }}$ birthday and Professor Roberto A. Rossi on his $6^{\text {th }}$ birthday \\ (received 27 Jun 03; accepted 12 Aug 03; published on the web 15 Aug 03)}

\begin{abstract}
Two new sterols, 1-2, unusually hydroxylated at C-21 have been isolated from the marine pulmonate Trimusculus peruvianus. Compound 2 possesses a $\Delta^{7}-3 \alpha, 5 \alpha, 6 \beta$-triol nucleus unprecedented in marine organisms. The structure and stereochemistries were determined on the basis of spectral studies, particularly NMR and MS spectroscopic data. 1 and $\mathbf{2}$ are the entire sterol content of the mollusk and both exhibit moderate in vitro cytotoxic activity against human colon carcinoma cell lines.
\end{abstract}

Keywords: Marine mollusk, Trimusculus peruvianus, $\Delta^{5}$ - and $\Delta^{7}$-polyhydroxylated steroids, cytotoxic activity

\section{Introduction}

Although shell-bearing mollusks such as intertidal pulmonate limpets of the family Trimusculidae are common marine invertebrates, only a limited number of chemical investigations on their metabolites have been reported. ${ }^{1}$ These sessile limpets, that live with unusual constraints, seem to produce de novo secondary metabolites, mostly diterpenes which appear to be involved in their defense against predators. ${ }^{2}$

In this work we report on the structure elucidation of two new polyhydroxylated steroids $\mathbf{1}$ and 2. Both compounds possess an identical side chain, unusually oxidized at C-21, and differ in the $\Delta^{5}$ - and $\Delta^{7}$-steroidal nucleus, respectively. Interestingly, although the $\Delta^{7}-3 \beta, 5 \alpha, 6 \beta$-triol nucleus is widespread in marine invertebrates ${ }^{3}$ and terrestrial plants, ${ }^{4}$ as well as in basidiomycete 
fungi, ${ }^{5}$ the $\Delta^{7}-3 \alpha, 5 \alpha, 6 \beta$-triol nucleus of 2 is unprecedented in naturally occurring marine steroidal metabolites.

Polyhydroxylated sterols are frequently found in marine invertebrates, ${ }^{3}$ such as alcyonarians, sponges, gorgonians, briozoos, starfish and bivalves, but they seem more rare in trimusculide mollusks. Four species of genus Trimusculus has been studied ${ }^{1}$ and, until now, only a sole steroidal metabolite, $\mathbf{3}$, isolated from Trimusculus conica, has been recently described. ${ }^{6}$

Compounds $\mathbf{1}$ and $\mathbf{2}$ exhibit moderate in vitro cytotoxic activity against human colon carcinoma cell lines.



Figure 1

\section{Results and Discussion}

General Procedures. From the crude ethyl acetate extract of $T$. peruvianus, collected near Antofagasta coast (Chile), compounds $\mathbf{1}$ and $\mathbf{2}$ were obtained after flash chromatography followed by gel filtration and successive HPLC.

\section{Structural analysis of 1: (20R)-cholest-5,24-diene-3 $\beta, 7 \beta, 21-$ triol}

Compound 1 was isolated as an oil. NMR data coupled with a $\mathbf{M}^{+}$peak at $m / z 416.3325$ in the HREIMS of 1 suggested a molecular formula of $\mathrm{C}_{27} \mathrm{H}_{44} \mathrm{O}_{3}$, indicating six degrees of unsaturation. The ${ }^{13} \mathrm{C}$ NMR spectrum of $\mathbf{1}$ (Table 1 ), together with the information from a DEPT spectrum, showed the presence of 27 well-resolved signals of which four were methyls (two olefinic), ten methylenes (one bearing oxygen), nine methines (two olefinic, and two geminal to oxygen) and four nonprotonated carbons (two olefinic). The ${ }^{13} \mathrm{C}$ NMR data and DEPT NMR experiment were consistent for an di-unsaturated C-27 sterol having three hydroxyl groups when compared with the reported values ${ }^{7}$ for a tetracyclic chlolestane nucleus (e. g., 4a, 4b, Figure 2 and Table 1).

The striking absence of the resonance of the C-21 methyl group, together with the presence of an oxymethylene carbon $\left(\delta_{\mathrm{H}}\right.$ : 3.68 and $\left.3.72 ; \delta_{\mathrm{C}} 62.7\right)$, suggested that the typical C-21 methyl group was oxidized to a primary hydroxyl function. 


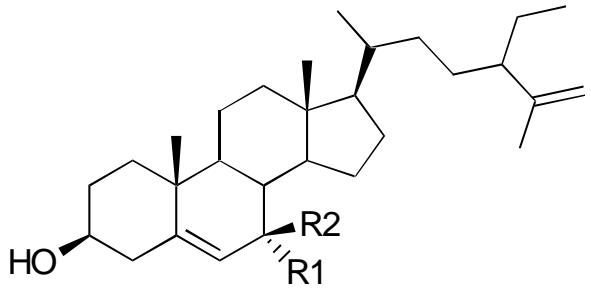

4b: $\mathrm{R}_{1}=\mathrm{H}, \mathrm{R}_{2}=\mathrm{OH}$

4a: $\mathrm{R}_{1}=\mathrm{OH}, \mathrm{R}_{2}=\mathrm{H}$

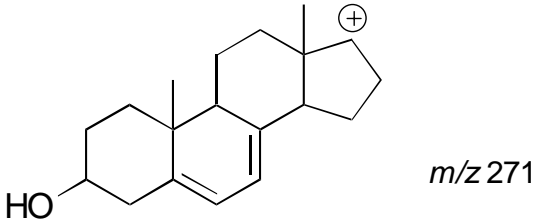

A

\section{Figure 2}

Besides the primary alcohol, the ${ }^{1} \mathrm{H}$ NMR showed resonances for two protons geminal to the remaining alcoholic oxygens at $\delta 3.85$ (ddd, $J=2.2,2.2,8.0 \mathrm{~Hz}$ ) and $\delta 3.55$ (dddd, $J=4.4,4.4$, $11.3,11.3 \mathrm{~Hz}$ ) completing, with that of the C-21 hydroxymethylene, the three oxygens present in the molecular formula. In addition, the ${ }^{1} \mathrm{H}$ NMR spectrum displayed signals for two olefinic protons $[\delta 5.29(\mathrm{t}, J=2.0 \mathrm{~Hz}), \delta 5.11(\mathrm{tt}, J=1.3,7.1 \mathrm{~Hz})]$ and for two olefinic and two angular methyl groups at $\delta 1.61, \delta 1.69, \delta 0.71$ (s) and $\delta 1.05$ (s), respectively. The HMBC correlation of both the $\mathrm{H}_{2}-21$ methylene alcohol and the $\mathrm{H}_{3}-18$ methyl group with $\mathrm{C}-17$ corroborated the position of the primary alcohol in the $\mathrm{C}-21$ side chain.

The location of the remaining functionalities was deduced by a combination of COSY NMR, HMQC and HMBC experiments. From the ${ }^{1} \mathrm{H}-{ }^{1} \mathrm{H}$ COSY NMR spectrum the isolated $\mathrm{H}_{2}-2-\mathrm{H}-$ 3- $\mathrm{H}_{2}-4$ and $\mathrm{H}-6-\mathrm{H}-7-\mathrm{H}-8$ spin systems were inferred, and by the HMBC correlations (Table 1) hydroxylic functions at C-3 and C-7, and trisubtituted double bonds at $\Delta^{5(6)}$ and $\Delta^{23(24)}$ were placed. The gross steroidal nucleus was corroborated by the MS spectrum of $\mathbf{1}$, which showed a peak at $m / z 271$ corresponding to fragment A, Figure 2. These data support the structure proposed for 1 .

Chemical shift arguments and 2D NOESY experiments established the relative configurations of the chiral centers of the rings. The chemical shifts and the vicinal coupling $\mathrm{H}$ $3 / \mathrm{H}_{2}-2, \mathrm{H}_{2}-4$ and $\mathrm{H}-7 / \mathrm{H}-6, \mathrm{H}-8$ are in agreement with the respective protons of a $\Delta^{5}-3 \beta, 7 \beta$-diol nucleus $^{7}$ (4a, Table 1). This was corroborated by the NOEs observed between $\mathrm{H}-4 \alpha / \mathrm{H}-3, \mathrm{H}-6$; $\mathrm{H}-6$ with $\mathrm{H}-7$; and $\mathrm{H}-7 / \mathrm{H}-9, \mathrm{H}-14$. The NOE observed between $\mathrm{H}-4 \beta$ and $\mathrm{H}_{3}-19$ placed the methyl group at $\mathrm{C}-10$ in the $\beta$ axial position. The $\beta$ stereochemistry of the lateral side chain linked to C-17 was consistent with the NOE observed between $\mathrm{H}_{3}-18$ and $\mathrm{H}_{2}-21$.
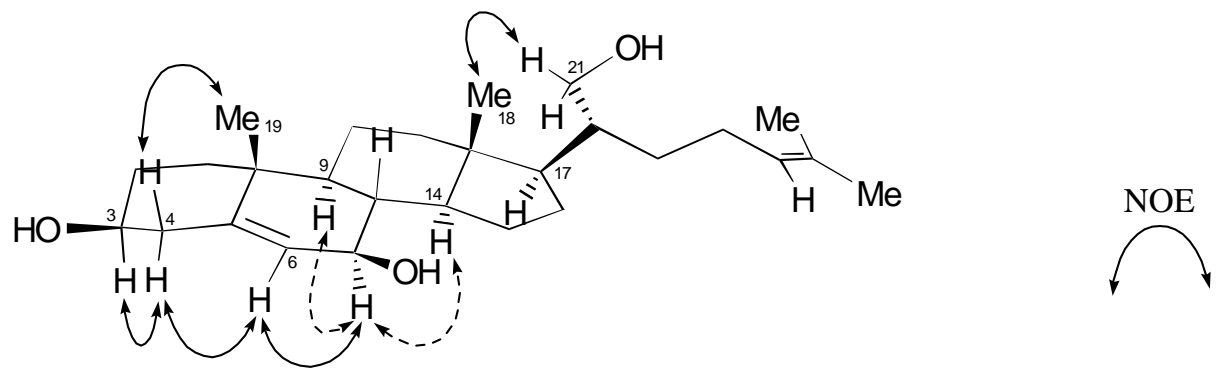


\section{Figure 3}

Table 1. ${ }^{1} \mathrm{H},{ }^{13} \mathrm{C}$ NMR and HMBC Data of compound $1\left[500 \mathrm{MHz}, \delta \mathrm{ppm},(J) \mathrm{Hz}, \mathrm{CDCl}_{3}\right]$ and ${ }^{13} \mathrm{C}$ NMR data of compounds $\mathbf{4 a}$ and $\mathbf{4 b}$

\begin{tabular}{|c|c|c|c|c|c|}
\hline \multirow{2}{*}{$\#$} & \multicolumn{3}{|c|}{1} & \multirow{2}{*}{$\frac{4 \mathrm{a}}{\delta_{\mathrm{C}}}$} & \multirow{2}{*}{$\frac{4 \mathrm{~b}}{\delta_{\mathrm{C}}}$} \\
\hline & $\delta_{\mathrm{H}}$ & $\delta_{\mathrm{C}}$ & HMBC & & \\
\hline \multirow[t]{2}{*}{1} & $1.06 \mathrm{~m}$ & 36.9 & C-5 & 36.8 & 36.9 \\
\hline & $1.84 \mathrm{~m}$ & & & & \\
\hline \multirow[t]{2}{*}{2} & $1.55 \mathrm{~m}$ & 31.5 & C-3, C-4 & 31.5 & 31.2 \\
\hline & $1.85 \mathrm{~m}$ & & & & \\
\hline 3 & 3.55 dddd $(4.4,4.4,11.3,11.3)$ & 71.4 & & 71.4 & 71.0 \\
\hline \multirow[t]{2}{*}{4} & $\alpha: 2.26$ ddd $(2.0,2.0,11.3)$ & 41.7 & C-2, C-3, C-5, C-6, & 41.6 & 41.6 \\
\hline & $\beta: 2.34$ ddd $(2.1,4.9,13.2)$ & & C-10 & & \\
\hline 5 & & 143.5 & & 143.4 & 142.3 \\
\hline 6 & $5.29 \mathrm{t}(2.0)$ & 125.4 & C-4, C-10 & 125.3 & 124.1 \\
\hline 7 & 3.85 ddd $(2.2,2.2,8.0)$ & 73.2 & C-5, C-6, C-14 & 73.3 & 65.4 \\
\hline 8 & $1.45 \mathrm{~m}$ & 40.9 & & 40.8 & 37.2 \\
\hline 9 & $1.04 \mathrm{~m}$ & 48.2 & & 48.2 & 42.1 \\
\hline 10 & & 36.4 & & 36.2 & 36.2 \\
\hline 11 & $1.53 \mathrm{~m}$ & 21.0 & C-9 & 21.0 & 20.9 \\
\hline \multirow[t]{2}{*}{12} & $1.21 \mathrm{~m}$ & 38.9 & & 39.5 & 39.8 \\
\hline & $1.94 \mathrm{~m}$ & & & & \\
\hline 13 & & 42.7 & & 42.8 & 42.8 \\
\hline 14 & $1.17 \mathrm{~m}$ & 55.8 & & 55.9 & 49.4 \\
\hline 15 & $1.95 \mathrm{~m}$ & 24.9 & & 26.4 & 26.4 \\
\hline 16 & $1.45 \mathrm{~m}$ & 27.7 & & 29.4 & 29.3 \\
\hline 17 & $1.40 \mathrm{~m}$ & 49.7 & & 55.3 & 55.7 \\
\hline 18 & $0.71 \mathrm{~s}$ & 12.1 & C-12, C-13, C-14, C-17 & 11.7 & 11.6 \\
\hline 19 & $1.05 \mathrm{~s}$ & 19.1 & C-5, C-9, C-10 & 19.1 & 19.8 \\
\hline 20 & $1.45 \mathrm{~m}$ & 42.0 & & 35.4 & 36.3 \\
\hline \multirow[t]{2}{*}{21} & 3.68 dd $(4.5,11.2)$ & 62.7 & רכ ח 17 ב & 18.6 & 18.6 \\
\hline & 3.72 dd $(3.3,11.2)$ & & $C-1 /, C-22$ & & \\
\hline 22 & $1.45 \mathrm{~m}$ & 29.4 & & 33.6 & 33.6 \\
\hline 23 & $1.90 \mathrm{~m}$ and $2.09 \mathrm{~m}$ & 26.2 & C-22, C-24, C-25 & 29.9 & 29.6 \\
\hline 24 & $5.11 \mathrm{tt}(1.3,7.1)$ & 124.7 & C-26, C-27 & 49.4 & 49.4 \\
\hline 25 & & 131.5 & & 17.7 & 17.7 \\
\hline 26 & $1.69 \mathrm{~s}$ & 25.7 & C-24, C-25 & 147.6 & 147.6 \\
\hline 27 & $1.61 \mathrm{~s}$ & 17.7 & C-24, C-25 & 111.3 & 111.3 \\
\hline
\end{tabular}




\begin{tabular}{lll}
\hline $\mathbf{2 8}$ & 26.3 & 26.3 \\
$\mathbf{2 9}$ & 11.8 & 11.9 \\
\hline
\end{tabular}

\section{Structural analysis of 2: (20R)-cholest-7,24-diene-3 $\alpha, 5 \alpha, 6 \beta, 21$-tetrol}

Compound 2, Figure 1, was isolated as an oil. NMR data coupled with a $\mathrm{M}^{+}$peak at $\mathrm{m} / \mathrm{z}$ 414.3181 in the HREIMS suggested a molecular formula of $\mathrm{C}_{27} \mathrm{H}_{44} \mathrm{O}_{4}$, indicating six degrees of unsaturation. The ${ }^{13} \mathrm{C}$ NMR spectrum of $\mathbf{2}$ (Table 2), together with the information from a DEPT spectrum, showed the presence of 27 signals of which four were methyls (two olefinic), ten methylenes (one bearing oxygen), eight methines (two olefinic, and two geminal to oxygen) and five nonprotonated carbons (two olefinic and one bearing oxygen).

The missing C-21 methyl group, the presence of an oxymethylene carbon $\left(\delta_{\mathrm{H}}: 3.66\right.$ and 3.71; $\delta_{\mathrm{C}}$ 62.7), and the ${ }^{13} \mathrm{C}$ chemical shifts of the respective C-20-C-27 fragments of $\mathbf{1}$ and $\mathbf{2}$ (Tables $1,2)$ suggested that both compound possessed an identical side chain. Taking into account the extra oxygen of the molecular formula and the DEPT spectrum, showing one additional quaternary carbon bearing oxygen and one methine less than $\mathbf{1}$, an unsaturated trihydroxylated nucleus for $\mathbf{2}$ was deduced. The almost identical ${ }^{13} \mathrm{C}$ NMR chemical shifts of C-17 and C-18 of $\mathbf{1}$ and 2 suggested that their differences are limited to ring A-C.

The rather high-field position of $\mathrm{H}_{3}-18$ methyl resonance at $\delta 0.56$, relative to the corresponding methyl group $(\delta 0.71)$ of $\mathbf{1}$, is in good agreement ${ }^{8}$ with a $\Delta^{7}$ - rather than a $\Delta^{5}$ sterol suggesting, at first glance, that the $\Delta^{7(8)}-3 \beta, 5 \alpha, 6 \beta$-triol nucleus, common in marine invertebrates, ${ }^{9}$ may be present in $\mathbf{2}$. Assuming that those are really the relative positions of these functionalities, the hydroxyl group at C-3 must possesses an $\alpha$-stereochemistry in virtue of the chemical shift and the small coupling constants $(J=5.5 \mathrm{~Hz})$ of $\mathrm{H}-3$ with the adjacent methylene protons (Table 2). The alternative $3 \beta$-hydroxyl in a cis- $\mathrm{A} / \mathrm{B}$ ring fusion, Figure 4 , is also compatible with the coupling constants, but is in disagreement with a ${ }^{13} \mathrm{C}$ chemical shift observed at $\delta$ 18.6, which is the value to be expected for a C-19 methyl group in a $5 \alpha$-steroid rather than in a $5 \beta$-steroid, where it should be deshielded about $11 \mathrm{ppm}$ by the absence of $\gamma$-gauche interaction. ${ }^{10}$

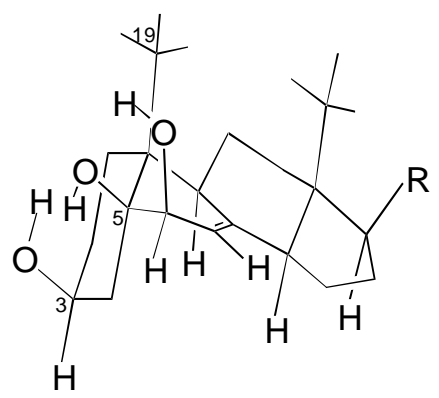<smiles>[R]CC(C)CCC=C(C)C</smiles>

\section{Figure 4}

The location of these functionalities on the rings, as mentioned above, was corroborated by a combination of COSY NMR, HMQC and HMBC experiments. From the COSY spectrum the 
$\mathrm{H}_{2}-2-\mathrm{H}-3-\mathrm{H}_{2}-4$ and $\mathrm{H}-6-\mathrm{H}-7$ spin systems were established, and by HMBC correlations (Table 2) a $\Delta^{7(8)}$ endocyclic olefin and hydroxylic functions were placed at C-3, C-5 and C-6.

Table 2. ${ }^{1} \mathrm{H},{ }^{13} \mathrm{C}$ NMR and HMBC Data of compound $2\left[500 \mathrm{MHz}, \delta\right.$ ppm, $\left.(J) \mathrm{Hz}, \mathrm{CDCl}_{3}\right]$ and ${ }^{13} \mathrm{C}$ NMR data of compound 5

\begin{tabular}{|c|c|c|c|c|}
\hline \multirow{2}{*}{$\#$} & \multicolumn{3}{|c|}{2} & \multirow{2}{*}{$\frac{5}{\delta_{C}}$} \\
\hline & $\delta_{\mathrm{H}}$ & $\delta_{\mathrm{C}}$ & HMBC & \\
\hline 1 & $\begin{array}{l}1.23 \mathrm{~m} \\
1.91 \mathrm{~m}\end{array}$ & 35.3 & C-2, C-3, C-5, C10, C-18 & 32.8 \\
\hline 2 & $\begin{array}{l}1.55 \mathrm{~m} \\
1.80 \mathrm{~m}\end{array}$ & 29.7 & C-3, C-10 & 30.4 \\
\hline 3 & $4.40 \mathrm{t}(5.5)$ & 76.9 & C-1, C-5 & 67.2 \\
\hline 4 & $\begin{array}{l}1.31 \mathrm{~m} \\
1.97 \mathrm{~m}\end{array}$ & 41.1 & & 39.3 \\
\hline 5 & & 78.1 & & 75.9 \\
\hline 6 & $4.06 \mathrm{~d}(5.2)$ & 79.0 & C-5, C-7, C-8, C-10 & 73.0 \\
\hline 7 & $5.38 \mathrm{~d}(5.2)$ & 111.6 & C-5, C-9, C-14 & 117.3 \\
\hline 8 & & 145.4 & & 143.2 \\
\hline 9 & $1.55 \mathrm{~m}$ & 52.3 & C-1, C-5, C-7, C-8, C-10, C-11, C-14 & 43.2 \\
\hline 10 & & 38.1 & & 37.0 \\
\hline 11 & $1.55 \mathrm{~m}$ & 25.0 & C-8, C-9, C-12, C-13 & 22.0 \\
\hline 12 & $\begin{array}{l}1.38 \mathrm{~m} \\
1.90 \mathrm{~m}\end{array}$ & 40.3 & C-9, C-13, C-19 & 38.9 \\
\hline 13 & & 46.4 & & 43.6 \\
\hline 14 & $2.06 \mathrm{~m}$ & 56.6 & $\begin{array}{c}\text { C-7, C-8, C-9, C-12, C13, } \\
\text { C-15, C-16, C-19 }\end{array}$ & 54.7 \\
\hline 15 & $1.91 \mathrm{~m}$ & 21.1 & & 22.9 \\
\hline 16 & $1.60 \mathrm{~m}$ & 26.7 & & 28.0 \\
\hline 17 & $1.62 \mathrm{~m}$ & 50.3 & C-13, C-19, C-20 C-21, C-22 & 55.9 \\
\hline 18 & $0.56 \mathrm{~s}$ & 12.4 & C-12, C-13, C-14, C-17 & 12.3 \\
\hline 19 & $1.10 \mathrm{~s}$ & 18.6 & C-1, C-5, C-9, C-10 & 18.3 \\
\hline 20 & $1.45 \mathrm{~m}$ & 42.4 & C-13, C-21 & 40.4 \\
\hline 21 & $\begin{array}{l}1.50 \mathrm{~m} \\
1.60 \mathrm{~m}\end{array}$ & 29.4 & C-20, C-23, C-24, C-27 & 19.6 \\
\hline 22 & $\begin{array}{l}3.66 \text { dd }(4.6,11.2) \\
3.71 \text { dd }(3.2,11.2)\end{array}$ & 62.7 & C-17, C-20, C-21 & 131.9 \\
\hline 23 & $\begin{array}{l}1.90 \mathrm{~m} \\
2.06 \mathrm{~m}\end{array}$ & 27.7 & C-24, C-25 & 135.3 \\
\hline 24 & $5.11 \mathrm{t}(7.1)$ & 124.7 & C-26, C-27 & 42.8 \\
\hline
\end{tabular}




\begin{tabular}{llcll}
\hline $\mathbf{2 5}$ & & 131.5 & & 33.1 \\
$\mathbf{2 6}$ & $1.68 \mathrm{~s}$ & 25.7 & C-24, C-25, C-27 & 19.9 \\
$\mathbf{2 7}$ & $1.61 \mathrm{~s}$ & 17.7 & C-24, C-25, C-26 & 21.1 \\
\hline
\end{tabular}

MS spectra has been a useful tool in steroidal structures elucidation. For example, in a series of eight $\Delta^{7(8)}-3 \beta, 5 \alpha, 6 \beta$-trihydroxysterols, isolated from a sponge, ${ }^{8}$ the molecular ion was absent. However, the presence in the MS spectrum of each compound of fragment B peak at $\mathrm{m} / \mathrm{z} 287$, which illustrated characteristic losses of water and side-chain, allowed to determine the gross steroidal nucleus. Thus, the two a.m.u less peak at $m / z 285$ of 2 compared with the former diagnostic peak at $m / z 287$ is consistent with a peroxy fragment $C$ (Figure 5) and, interestingly, it supported the $3 \alpha, 5 \alpha$ stereochemistry of an $\Delta^{7}-3 \alpha, 5 \alpha, 6 \beta$-triol nucleus. Therefore, there are two easily distinguished fragment peak in each of the MS spectra which provide a straightforward assignment of an $\Delta^{7(8)}-3 \beta, 5 \alpha, 6 \beta$ - and a $\Delta^{7(8)}-3 \alpha, 5 \alpha, 6 \beta$-trihydroxysterol, for example in a routine GC-MS analysis.

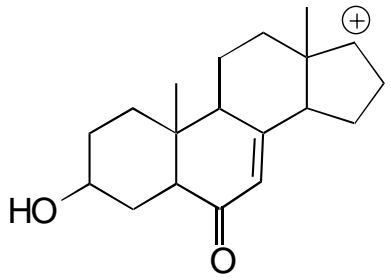

B

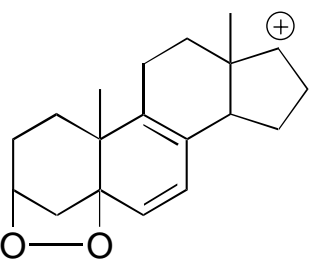

C

$m / z 285$

\section{Figure 5}

We were intrigued by the prominent strong shielding resonances of carbons C-7 and C-9 of 2 when compared with the respective carbons of the $\Delta^{7(8)}-3 \beta, 5 \alpha, 6 \beta$-nucleus of cerevisterol 5 , $^{5}$ Figure 6, Table 2. Although they are epimeric at C-3 this did not seem sufficient to justify insight differences of $\Delta \delta \sim 6$ and $\Delta \delta \sim 9 \mathrm{ppm}$, respectively. Thus, molecular mechanics calculations were performed to gain insight about the spatial disposition of the hydroxylic functions. The minimization $^{11}$ of the structure revealed a most favorable conformation 2, Figure 6, involving a H-bond interaction between $3 \alpha$ - and $5 \alpha$-hydroxyls, with the alcoholic proton of the $\mathrm{C}_{5}-\mathrm{OH}$ oriented towards the centre of the $\alpha$ face of ring $B$. This arrangement would induce some stereoelectronic conformational changes that nicely explain certain shielded carbon resonances observed. The combination of both $\mathrm{MS}$ and ${ }^{13} \mathrm{C}$ NMR spectral studies provides an accurate method to distinguish a C-3 epimeric $\Delta^{7(8)}-3,5 \alpha, 6 \beta$-steroidal nucleus.

Chemical shift arguments and 2D NOESY experiments confirmed the above proposed relative configurations of the chiral centers of the rings. The small coupling constants observed for $\mathrm{H}-3$ with the adjacent methylene indicate that it must be equatorial with a $3 \alpha-\mathrm{OH}$ stereochemistry. As the chemical shift and coupling constant of H-6 are in agreement with the corresponding proton of a $6 \beta$-hydroxysteroid such as 5 , Figure 5 , compound 2 possesses a $\Delta^{7}$ $3 \alpha, 5 \alpha, 6 \beta$-trihydroxy nucleus. The $\beta$ stereochemistry of the lateral side chain linked to $\mathrm{C}-17$ was consistent with the NOE observed between $\mathrm{H}_{3}-18$ and $\mathrm{H}_{2}-21$. 


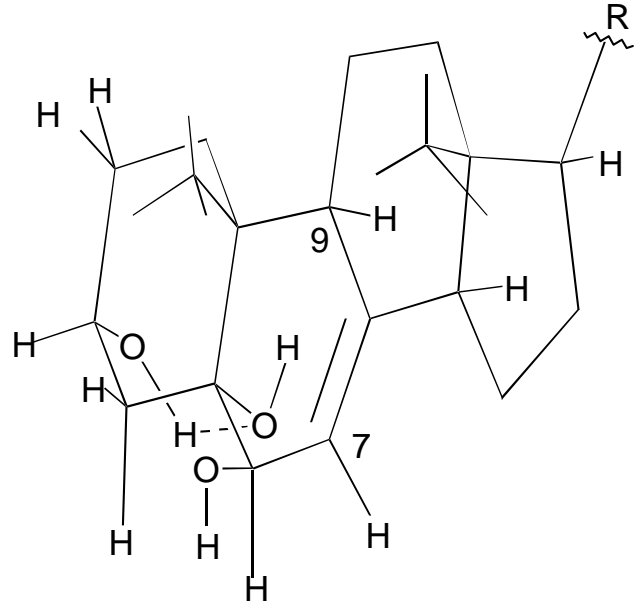

2<smiles>[R]CC(C)CCC=C(C)C</smiles><smiles>CC(C)C(C)/C=C/[C@H](C)[C@H]1CCC2C3=C[C@H](O)[C@@]4(O)CC(O)CC[C@]4(C)C3CC[C@]21C</smiles>

5

\section{Figure 6}

\section{C-20 configuration of 1 and 2}

Although the angular methyl proton shielding permits stereochemical assignment in many systems, there are cases where it is not possible, marked ${ }^{13} \mathrm{C}$ shielding differences being a better way to resolve stereochemical problems. ${ }^{12}$ It has been reported ${ }^{13}$ that synthetic 21 -hydroxysterols of the $20 \mathrm{R}$ series (natural configuration) exhibit a proton resonance at $\delta 3.70$ as a singlet ($\mathrm{CH}_{2} \mathrm{OH}$ ), while those of the $20 \mathrm{~S}$ configuration show a multiplet centered at $\delta 3.62$. Consequently, the chemical shift ( $\delta 3.66 \mathrm{dd}$ and $3.71 \mathrm{dd}$ ), but not the multiplicities of the signals, of the hydroxymethylene of $\mathbf{1}$ and $\mathbf{2}$ are in agreement with a 20 R configuration. Unfortunately, that report is devoid of any ${ }^{13} \mathrm{C}$ NMR data for additional comparison.

Further considerations of ${ }^{13} \mathrm{C}$ NMR data showed that the C-17 chemical shift $(\delta \sim 50 \mathrm{ppm})$ of compounds $\mathbf{1}$ and $\mathbf{2}$ is shielding by 5 ppm when compared with the corresponding C-17 in a reduced C-21 carbon (21- $\mathrm{CH}_{3}$ ) of compounds $\mathbf{4 a}$, $\mathbf{4 b}$ (Tables 1 and 2) and 5, Figure 7 (depicted as ring $\mathrm{D}$ and side-chain only). Also, in both 21- $\mathrm{CH}_{2} \mathrm{OH}$ and 21- $\mathrm{CH}_{3}$ compounds $7 \mathbf{a}$ and $\mathbf{7 b}$, respectively, isolated from a basidiomycete fungus ${ }^{14}$ and with a known $20 \mathrm{R}$ configuration, similar shielding differences $\Delta \delta_{\mathrm{ROH}}-\delta_{\mathrm{RH}} \sim 6$ were also found. This may be rationalized as C-17, in compounds $\mathbf{1}, \mathbf{2}$, and $\mathbf{7 a}$, are in a $\gamma$-gauche, 1,3 synperiplanar orientations, with the polar C-21hydroxyl substituent, absorbing at significantly higher field than their reduced counterparts of compounds 5 and $\mathbf{7 b}$. Thus, compounds 1 and $\mathbf{2}$ have a 20R configuration.

The $20 \mathrm{R}$ configuration of the naturally occurring 21-hydroxysteroid $\mathbf{6 a}$, Figure 7, isolated from a starfish, ${ }^{15}$ was also established on the basis of the chemical shift of $\mathrm{H}_{2}-21$. In this and other 21-hydroxy related steroids, isolated from the same source, the corresponding C-17 resonated at $\sim \delta 50.5 \mathrm{ppm}$ also, providing additional evidence of the utility of the $\mathrm{C}$-21 shielding effect on C-17 to establish the configuration at C-20.

Compounds 1 and 2 exhibit moderate in vitro cytotoxicity against H-116 and HT-29 (human colon carcinoma) cell lines, displaying $\mathrm{IC}_{50}$ values of 2.5 and $12.5 \mu \mathrm{g} / \mathrm{mL}$, respectively, in each case. 


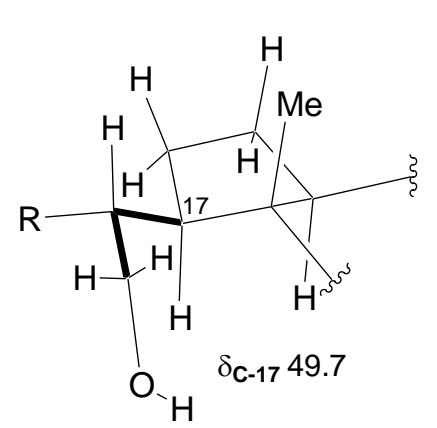<smiles>[R]CC(C)CCC=C(C)C</smiles>

\section{1,2}<smiles>[R]CC(C)CCC(=C)C(C)C</smiles>

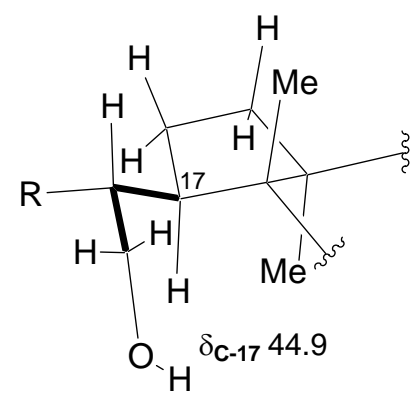<smiles>[R]CC(C)CCC=C(C)C</smiles>
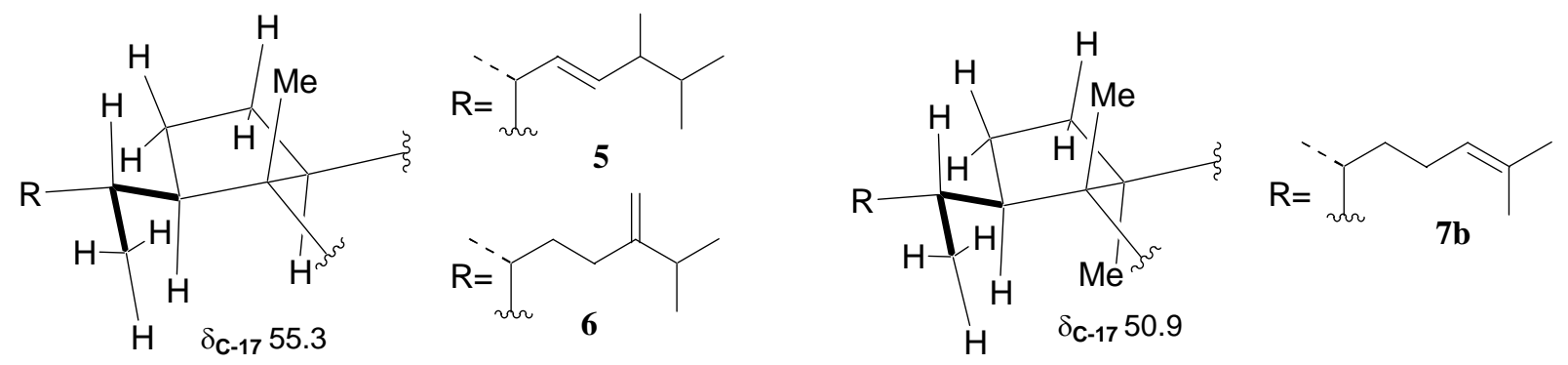

$$
\Delta\left(\delta_{\mathrm{ROH}^{-}} \delta_{\mathrm{RH}}\right)=-5.6
$$

$$
\Delta\left(\delta_{\mathrm{ROH}}-\delta_{\mathrm{H}}\right)=-6.0
$$

Figure 7

\section{Conclusions}

Two new sterols 1-2, unusually hydroxylated at C-21, have been isolated from the marine pulmonate Trimusculus peruvianus, 2 being an unprecedented $\Delta^{7}-3 \alpha, 5 \alpha, 6 \beta$-triol nucleus. The cis stereochemistry of the $3 \alpha, 5 \alpha$-diol moiety of nucleus produced a characteristic $m / z$ peak in the MS spectrum and the ${ }^{13} \mathrm{C}$ shielding resonances of C-7 and C-9 that provided a straightforward and accurate method to distinguish at the C-3 epimeric $\Delta^{7(8)}-3,5 \alpha, 6 \beta$-steroidal nucleus. C-21 substituents shielding effect on $\mathrm{C}-17$, due to $\gamma$-gauche interaction, provided a method to establish the configuration at C-20.

\section{Experimental Section}

General Procedures. Optical rotations were measured on a Perkin-Elmer model 343 Plus using a Na lamp at $25^{\circ} \mathrm{C}$. IR spectra were obtained with a Perkin-Elmer 1650/FTIR spectrometer in $\mathrm{CHCl}_{3}$ solutions. ${ }^{1} \mathrm{H}$ NMR and ${ }^{13} \mathrm{C}$ NMR, HMQC, HMBC and COSY spectra were measured at $500 \mathrm{MHz}$ for ${ }^{1} \mathrm{H}$ NMR and at $125 \mathrm{MHz}$ for ${ }^{13} \mathrm{C}$ NMR. Two-dimensional NMR spectra were 
obtained with the standard Bruker software. EIMS and HRMS data were taken on a Micromass Autospec spectrometer. HPLC separations were performed with a Hewlett Packard 1050 (JaigelSil preparative column 10 $\mu 20 \times 250 \mathrm{~mm}$ ) with hexane-EtOAc mixtures. The gel filtration column (Sephadex LH-20) used hexane- $\mathrm{MeOH}-\mathrm{CH}_{2} \mathrm{Cl}_{2}$ (3:1:1) as solvent. Merck Si gels 7734 and 7729 were used in column chromatography. The spray reagent for TLC was $\mathrm{H}_{2} \mathrm{SO}_{4}-\mathrm{H}_{2} \mathrm{O}-\mathrm{AcOH}$ $(1: 4: 20)$.

Biological material. Specimens of Trimusculus peruvianus were collected on intertidal rocks near Antofagasta, III Region of Chile, in November, 2001. A voucher specimen has been deposited at the Facultad de Ciencias, Universidad de Antofagasta, collection.

Extraction and isolation. 600 Freeze-dried specimens of $T$. peruvianus were extracted with ethyl acetate at room temperature and concentrated to give a dark residue (10.7 g). The extract was chromatographed by flash chromatography on silica gel. The fraction eluted with hexane: EtOAc (70:30) (804 mg) was chromatographed on a LH-20 column to give a complex mixture that was further separated by HPLC to give compound 2 (14.0 mg). The fraction eluted with hexane: EtOAc (50:50) (718 mg) was chromatographed on a Sephadex LH-20 column, affording a fraction that was chromatographed by HPLC to give compound $\mathbf{1}$ (3.8mg).

Compound (1). Colorless oil, $[\alpha]_{\mathrm{D}}{ }^{25}-20$ (c 0.25, $\mathrm{CHCl}_{3}$ ), IR (film) $v_{\max } 3344,2930,2864 \mathrm{~cm}^{-1}$;

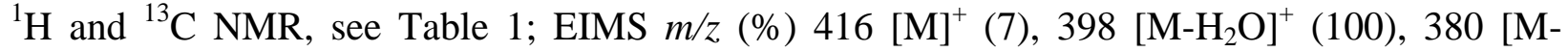
$\left.2 \mathrm{H}_{2} \mathrm{O}\right]^{+}$(19), 287 (7); HREIMS m/z [M] 416.3325 (calcd for $\mathrm{C}_{27} \mathrm{H}_{44} \mathrm{O}_{3}, 416.3290$ ), 398.3220 (calcd for $\mathrm{C}_{27} \mathrm{H}_{42} \mathrm{O}_{2}$, 398.3185).

Compound (2). Colorless oil; $[\alpha]_{\mathrm{D}}^{25}+53$ (c 0.58, $\mathrm{CHCl}_{3}$ ), IR (film) $v_{\max }$ 3381, 2940, 2864,

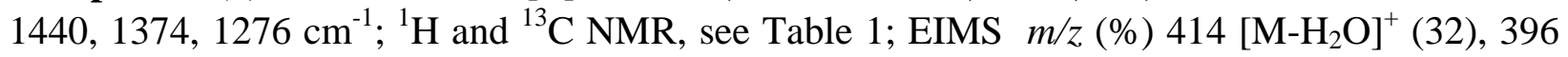
$\left[\mathrm{M}-2 \mathrm{H}_{2} \mathrm{O}\right]^{+}$(27), 285 (82), 69 (100); HREIMS m/z [M- $\left.\mathrm{H}_{2} \mathrm{O}\right]^{+} 414.3181$ (calcd for $\mathrm{C}_{27} \mathrm{H}_{42} \mathrm{O}_{3}$, 414.3134), 396.3098 (calcd for $\mathrm{C}_{27} \mathrm{H}_{40} \mathrm{O}_{2}$, 396.3028), 285.1902 (calcd for $\mathrm{C}_{19} \mathrm{H}_{25} \mathrm{O}_{2}, 285.1855$ ).

\section{Acknowledgments}

This work was supported by the Ministerio de Ciencia y Tecnología (MCYT), project ref: PPQ2002-02494, DGUI of the Canary Islands Government PI2002/044, DID project CSMAR 02/6-2 of the Universidad de Chile, Cooperation Program between CSIC (Spain)-CONICYT (Chile), and DI of the Universidad de Antofagasta. We are grateful to BIOMAR, S.A., for performing the bioassays. A. R. D.-M. acknowledges an I3P grant from the CSIC and E. D. an FPI grant from the MCYT.

\section{References}


1. (a) Manker, D. C.; Faulkner, D. J. Tetrahedron 1987, 43, 3677. (b) Gray, C. A.; DaviesColeman, M. T.; McQuaid, C. Nat. Prod. Letters 1998, 12, 47. (c) Rovirosa, J.; Quezada, E.; San-Martín, A. Bol. Soc. Chil. Quím 1992, 37, 143. (d) San-Martín, A.; Quezada, E.; Soto, P.; Palacios, Y.; Rovirosa, J. Can. J. Chem. 1996, 74, 2471. (e) Díaz-;Marrero, A. R.; Dorta, E.; Cueto, M.; Rovirosa, J.; San-Martín, A.; Loyola, A.; Darias, J. Tetrahedron 2003, 59, 4805.

2. Faulkner, D. J. In Chemical Defenses of Marine Molluscs; Paul V.J., Ed.; Ecological Roles of Marine Natural Products. Cornell University Press, Ithaca: New York, 1992, pp 118-163.

3. Blunt, J. W.; Copp, B. R.; Munro, M. H. G.; Northcote, P. T.; Prinsep, M. R. Nat. Prod. Rep. 2003, 20, 1 and references cited therein.

4. (a) El-Mekkawy, S.; Meselhy, R.; Nakamura, N.; Tezuka, Y.; Hattori, M.; Kakiuchi, N; Shimotohno, T.; Kawahata, T.; Otake, T. Phytochemistry 1998, 49, 1651. (b) Su, H-J.; Fann, Y-F.; Chung, M-I.; Won, S-J.; Lin, C-N. J. Nat. Prod. 2000, 63, 514.

5. Kawagishi, H.; Katsumi, R.; Sazawa, T; Mizuno, T; Hagiwara, T; Nakamura, T. Phytochemistry 1988, 27, 2777.

6. Manker, D. C.; Faulkner, D. J. J. Chem. Ecol. 1996, 22, 23.

7. Ahmad, V. U.; Aliya, R.; Shameel, M. Phytochemistry 1993, 33, 1189.

8. Piccialli, V.; Sica, Donato. J. Nat. Prod. 1987, 50, 915.

9. (a) Ciminiello, P.; Fattorusso, E.; Magno, S.; Mangoni, A.; Pansini, M. J. Am. Chem. Soc. 1990, 112, 3505. (b) Aiello, A.; Ciminiello, P.; Fattorusso, E.; Magno, S. J. Nat. Prod. 1988, 51, 999. (c) Iorizzi, M.; Minale, L.; Riccio, R.; Lee. J.-S.; Yasumoto, T. J. Nat. Prod. 1988, 51, 1098. (d) Cafieri, F.; Fattorusso, E.; Gavagnin, M.; Santacroce, C. J. Nat. Prod. 1985, 48, 944.

10. (a) Gouch, J. L.; Guthrie, J. P. J. Chem. Soc., Chem. Commun. 1972, 979. (b) Blunt, J. W. Aust. J. Chem. 1975, 28, 1017.

11. PCModel (v.7.0); Serena Software: Bloomington, IN, 47402-3076.

12. (a) Reich, H. J.; Jautelat, M.; Messe, M. T.; Weigert, F. J.; Roberts, J. D. J. Am. Chem. Soc. 1969, 91, 7445. (b) Eggert, H.; VanAntwerp, C. L.; Bhacca, N. S.; Djerassi, C. J. J. Org. Chem. 1976, 41, 71.

13. Byon, C-y.; Büyüktür, G.; Choay, P.; Gut, M. J. Org. Chem. 1977, 42, 3619.

14. Rosecke, J.; König, W. A. Phytochemistry 1999, 52, 1621.

15. D’Auria M. V.; Finamore, E.; Minale, L.; Pizza, C.; Ricci, R.; Zollo, F. J. Chem. Soc., Perkin Trans I 1984, 2277. 